\title{
INTENSIVE TECHNOLOGIES ENERGY-, MASSTRANSFER DURING STERILIZATION OF FOOD PRODUCTS
}

\author{
Y. Stupak, K. Vasilkovskiy \\ National University of Food Technologies
}

\begin{tabular}{|c|c|}
\hline Key & \multirow{10}{*}{$\begin{array}{l}\text { Thermal sterilization is the most widespread and reliable } \\
\text { method of canning of foods. Sterilization of consistency of } \\
\text { products is related to their high temperature treatment in the } \\
\text { conditions of conductus heat exchange. Time of heating and } \\
\text { cooling of packing with consistency products is especially } \\
\text { prolonged. The use of rotary sterilization considerably abbre- } \\
\text { viates duration of process and improves quality of products. } \\
\text { In research the variants of structural decisions of the special } \\
\text { rotary devices for realization of difficult rotatory motion are } \\
\text { considered and the kinematics analysis of the offered } \\
\text { mechanical systems is executed. A ratio between speed and } \\
\text { geometrical parameters of mechanisms is determined. }\end{array}$} \\
\hline Intensification & \\
\hline Rotatory motion & \\
\hline Centrifugal force & \\
\hline Planetary mechanism & \\
\hline drive & \\
\hline Kinematics & \\
\hline $\begin{array}{l}\text { Instantaneous axis of } \\
\text { rotation }\end{array}$ & \\
\hline & \\
\hline $\begin{array}{l}\text { Received in rev } \\
04.12 .2017\end{array}$ & \\
\hline
\end{tabular}

Accepted 26.12.2017

Corresponding author:

K. Vasilkovskiy

E-mail:

npnuht@ukr.net

DOI: $10.24263 / 2225-2924-2017-23-6-12$

\section{IНТЕНСИВНI ТЕХНОЛОГIÏ ЕНЕРГО- I МАСООБМІНУ ПРИ СТЕРИЛІЗАЦІЇ ХАРЧОВОЇ ПРОДУКЦІї}

\author{
Ю.О. Ступак, К.В. Васильківський \\ Національний університет харчових технологій
}

Теплова стерилізаиія є найбільш розповсюдженим і надійним способом консервування харчових продуктів. Стерилізачія консистентної продукиї̈ пов 'язана $з$ іï високотемпературною обробкою в умовах кондуктивного теплообміну. Час нагрівання та охолодження упаковок з консистентною продукцією є особливо подовженим. Використання ротаційної стерилізаиії значно скорочує тривалість процесу і підвищує якість продукиї. У дослідженні розглянуто варіанти конструктивних рімень спеціальних ротаційних пристроїв для реалізаиії складного обертального руху і виконано кінематичний аналіз запропонованих механічних систем. Визначено співвідношення між швидкісними і геометричними параметрами механізмів.

Ключові слова: інтенсифікачія, обертальний рух, відиентрова сила, планетарний механізм, ланцюгова передача, кінематика, миттева вісь обертання. 
Постановка проблеми. Методи теплової обробки харчової продукції постійно удосконалюються. В основному зміни направлені на підвищення якості готової продукції, розширення асортименту тари за рахунок збільшення об'єму банок і підвищення економічної ефективності процесу обробки на основі проведення аналізу та виявлення шляхів інтенсифікації процесу стерилізації за умови зменшення енерговитрат і часу технологічного впливу.

Підвищення швидкості перехідних процесів нагрівання й охолодження консистентної продукції під час ії стерилізації має вирішальне значення не тільки з точки зору продуктивності технологічного обладнання, а й 3 точки зору якісних показників продукції, пов'язаних з ії перегріванням у локальних зонах. Співвідношення часу перебігу вказаних процесів має принципове значення. Для консистентної продукції єдиним і лімітуючим є процес передавання теплоти теплопровідністю. Останнє вимагає пошуку додаткових або нових рішень, направлених на інтенсифікацію теплообміну. Пов'язуючи інтенсивність теплообміну з гідродинамічним станом продукту в упаковці, розробники нової техніки стали на шлях використання потенціальних полів сил інерції для забезпечення перемішування вмісту банок, пляшок тощо.

Саме при ротаційній стерилізації під час обертання відбувається додаткове перемішування, вирівнювання температури і покращення умов теплопередачі. Ротаційна стерилізація знижує термічну інерцію харчових продуктів. Дослідження показують, що значення константи термічної інерції вдається зменшити в 6-7 разів, у результаті чого значно скорочується формула стерилізації.

Мета дослідження: аналіз конструктивних рішень спеціальних ротаційних пристроїв щодо інтенсифікації рівнів гідродинамічних дій, що дасть змогу підвищити швидкість теплообміну та скорочення часу перебігу перехідних процесів нагрівання й охолодження упаковок з консистентною продукцією.

Викладення основних результатів дослідження. Розглянемо деякі 3 випадків, що стосуються обертальних рухів і за рахунок яких створюються відцентрові сили. Нехай об'єкт маніпулювання виконано у вигляді вертикального циліндричного резервуара 3 можливістю обертання його навколо вертикальної осі з кутовою швидкістю $\omega$ (рис. 1).

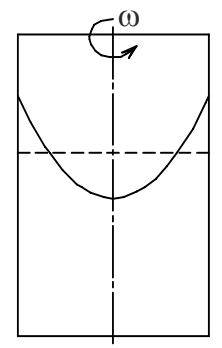

a

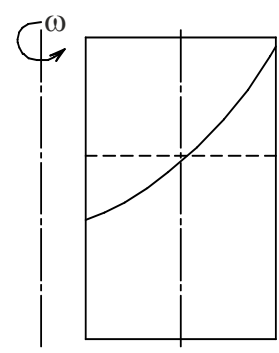

б

Рис. 1. Схема для визначення поверхні рідинного середовища

За рахунок сил тертя продукт також одержує обертальний рух з кутовою швидкістю, близькою до 
нення додаткового внутрішнього тиску за рахунок відцентрових сил. При цьому, за інших рівних умов, величини відцентрових сил визначаються відстанню від центра обертання. На рис.1а упаковка обертається навколо своєї геометричної осі, а на рис. 16 навколо вертикальної осі, яка не збігається з ії геометричною віссю. Очевидно, що за вказаних умов потенціальне поле сил інерції відносно продукту (і тари) є стабілізованим і не впливає на його гідродинамічний режим.

Відгуком систем по рис. 1а та 16 на створення полів відцентрових сил буде зміна поверхні рідинного середовища. Для випадку на рис. 1а оберемо поверхню параболоїда, а для випадку 3 асиметричним розташуванням осі обертання — частину поверхні параболоїда. Несиметричність останньої відносно упаковки вказує на можливість впливу на гідродинамічний стан об'єму продукту за рахунок надання одночасного 3 обертанням навколо асиметричної осі обертання навколо геометричної осі симетрії упаковки 3 кутовою швидкістю $\omega_{2}$. Наслідком такого суміщення двох обертальних рухів буде утворення біжучої хвилі на поверхні рідинної фази 3 додатковим радіальним і коловим перемішуванням.

Реалізувати даний складний обертальний рух можливо за допомогою планетарного механізму або ланцюгової передачі. Проаналізуємо кінематику руху (встановленням зв'язку лише між швидкісними характеристиками) як у першому, так і в другому випадку.

I. Планетарний механізм - складові обертання направлені в один бік (рис. 2). При співнаправлених складових обертання відносним буде обертання навколо осі $O_{2} 3$ кутовою швидкістю $\omega_{2}$, а переносним - обертання відносно осі $O_{H} 3$ кутовою швидкістю $\omega_{\mathrm{H}}$. Результуючим рухом співнаправлених обертань тіла навколо паралельних осей буде миттєве обертання тіла в тому ж напрямку 3 кутовою швидкістю $\omega$ навколо миттєвої осі обертання. Для випадку планетарного механізму миттєва вісь обертання пройде через полюс зачеплення точку $P$ паралельно осям $O_{2}$ і $O_{H}$.

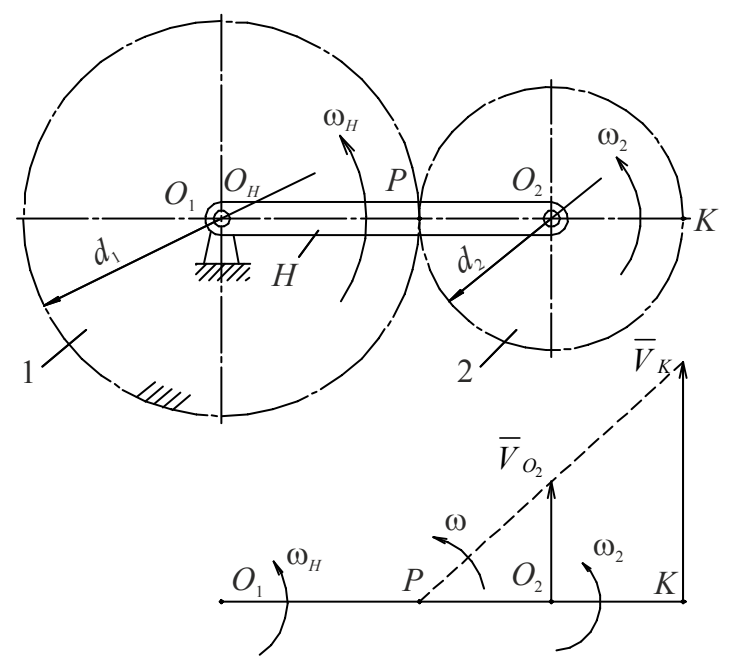

Рис. 2. Схема для випадку планетарного механізму 
Залежність між кутовими швидкостями визначається за формулою Вілліса:

$$
\begin{gathered}
i_{2 H}=1-i_{21}^{H} ; \\
i_{2 H}=1-(-1)^{k} \frac{z_{1}}{z_{2}}=1+\frac{z_{1}}{z_{2}},
\end{gathered}
$$

де $k$ - число пар зубчастих коліс, що знаходяться у зовнішньому зачепленні; $z_{1}, z_{2}$ - число зубців відповідних зубчастих коліс.

Звідки

$$
\omega_{2}=\omega_{H} \cdot\left(1+\frac{z_{1}}{z_{2}}\right),
$$

тоді отримаємо $\omega_{2}>\omega_{H}$.

Швидкості точок $\mathrm{O}_{2}$ і К визначаються залежностями:

$$
\begin{aligned}
& V_{O_{2}}=\omega_{H} \cdot H ; \\
& V_{K}=2 \omega_{H} \cdot H .
\end{aligned}
$$

Звідки

$$
\omega=\frac{V_{K}}{d_{2}}=\omega_{H} \cdot \frac{2 H}{d_{2}}=\omega_{2}
$$

де $d_{1}, d_{2}$ - діаметри ділильних кіл відповідних зубчастих коліс; $H=\frac{d_{1}+d_{2}}{2}-$ довжина водила.

Положення миттєвої осі обертання відносно геометричної осі упаковки:

$$
\mathrm{O}_{2} P=d_{2}=\frac{2 H}{i_{2 H}} .
$$

Таким чином, колова швидкість точок тіла вздовж його діаметра від точки $P$ до точки $K$ змінюється лінійно:

$$
0 \leq V_{i} \leq 2 \omega_{H} \cdot H .
$$

II. Ланцюгова передача - складові обертання направлені протилежно (рис. 3). Якщо відносний і переносний обертальні рухи навколо паралельних осей протилежні за напрямком і різні за величиною, то швидкості точок $O_{2}$ i $C$ направлені в одному напрямку. Миттєва вісь обертання $P$ у цьому випадку знаходиться не між осями $O_{H}$ і $O_{2}$, а розташована зовні з боку осі складового обертання з більшою кутовою швидкістю.

Залежність між кутовими швидкостями:

$$
\begin{gathered}
i_{2 H}=\frac{\omega_{2}}{\omega_{H}}=\frac{d_{1}}{d_{2}} ; \\
\omega_{2}=\omega_{H} \cdot \frac{d_{1}}{d_{2}},
\end{gathered}
$$

тоді отримаємо $\omega_{2}>\omega_{H}$, якщо $d_{1}>d_{2}$, де $d_{1}, d_{2}$ - ділильні діаметри зірочок. 
Враховуючи, що

$$
\omega=\frac{V_{O_{2}}}{O_{2} P}=\frac{V_{C}}{C P}=\frac{V_{O_{2}}-V_{c}}{O_{2} P-C P},
$$

та значення швидкості

$$
\begin{gathered}
V_{O_{2}}=\omega_{H} \cdot H, \\
\overline{V_{C}}=\overline{V_{C O_{1}}}-\overline{V_{C O_{2}}} \\
V_{C}=\omega_{H}\left(H+\frac{d_{2}}{2}\right)-\omega_{2} \frac{d_{2}}{2}=\omega_{H}\left(H+\frac{d_{2}}{2}-\frac{d_{1}}{2}\right),
\end{gathered}
$$

одержимо вирази для обчислення абсолютної кутової швидкості тіла та положення миттєвої осі обертання:

$$
\begin{gathered}
\omega=\omega_{2}-\omega_{H}, \\
\omega=\omega_{H}\left(\frac{d_{1}}{d_{2}}-1\right), \\
O_{2} P=\frac{V_{O_{2}}}{\omega}=\frac{\omega_{H} H}{\omega_{2}-\omega_{H}}=\frac{H d_{2}}{d_{1}-d_{2}}, \\
O_{2} P=\frac{H}{i_{2 H}-1} .
\end{gathered}
$$
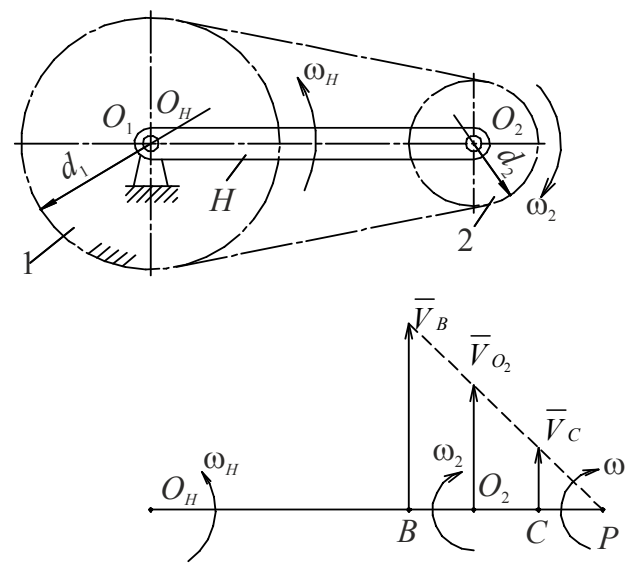

Рис. 3. Схема для випадку ланцюгового механізму

Отже, результуючий рух буде обертальним з абсолютною кутовою швидкістю, яка дорівнює різниці складових кутових швидкостей, у напрямку більшої кутової швидкості.

Таким чином, колова швидкість точок тіла вздовж його діаметра від точки $C$ до точки $B$ змінюється лінійно:

$$
\omega_{H}\left(H+\frac{d_{2}}{2}-\frac{d_{1}}{2}\right) \leq V_{i} \leq \omega_{H}\left(H-\frac{d_{2}}{2}+\frac{d_{1}}{2}\right) .
$$


Порівнюючи вирази для обчислення абсолютної $\omega$ та відносної $\omega_{2}$ кутової швидкості тіла за рівних значень довжини водила $H$ та його кутової швидкості $\omega_{H}$ в обох випадках, отримаємо:

- приріст колової швидкості точок тіла вздовж його діаметра:

$$
\begin{gathered}
\Delta V_{i(I)}=2 H \omega_{H}, \\
\Delta V_{i(I I)}=\omega_{H}\left(d_{1}-d_{2}\right) ;
\end{gathered}
$$

- співвідношення відносних кутових швидкостей:

$$
\frac{\omega_{2(I)}}{\omega_{2(I I)}}=\frac{2 H}{d_{1}}>1 ;
$$

- співвідношення абсолютних кутових швидкостей:

$$
\frac{\omega_{(I)}}{\omega_{(I I)}}=\frac{2 H}{\left(d_{1}-d_{2}\right)}>1 ;
$$

- співвідношення полюсних відстаней:

$$
\frac{O_{2} P_{(I)}}{O_{2} P_{(I I)}}=\frac{2 H\left(i_{2 H}-1\right)}{H i_{2 H}}=2-\frac{2}{i_{2 H}}>1 .
$$

\section{Висновки}

Отже, на основі проведеного аналізу кінематики запропонованих механізмів можна стверджувати, що в першому випадку (планетарний механізм) за рівних початкових умов кутові швидкості, полюсна відстань від осі упаковки є більшими і тому кривизна поверхні рідинної фази більш виражена, тобто отримаємо вищий ступінь перемішування продукту в тарі.

\section{Література}

1. Даиишин О.В. Механізація переробки і зберігання плодоовочевої продукції: Навч. посібник / О.В. Дацишин, О.В. Гвоздев, Ф.Ю. Ялпачик, Ю.П. Рогач // За ред. О.В. Дацишина - Київ : Мета, 2003. - 288 с.: іл.

2. Іскрицький B.M. Теоретична механіка. Статика і кінематика: Навчальний посібник / В.М. Іскрицький, С.В. Подлєсний, О.Г. Водолазська, Ю.О. Єрфорт. - Краматорськ : ДДМА, 2007. - $204 \mathrm{c}$.

3. Соколенко A.I. Фізико-хімічні методи обробки сировини та продуктів харчування / А.І. Соколенко, В.Б. Костін, К.В. Васильківський, О.Ю. Шевченко, В.Й. Лензіон, В.Г. Рєзнік // За ред. А.І. Соколенка. - Київ : АртЕк, 2000. — 306 с.

4. Соколенко A.I. Інтенсифікація масообмінних процесів в харчових і мікробіологічних технологіях / А.І. Соколенко, О.Ю. Шевченко, В.А. Піддубний. — Київ : ПП «Люксар», 2007. $-443 \mathrm{c}$.

5. Соколенко А.І. Інтенсифікація теплообміну при ротаційній стерилізації / А.І. Соколенко, К.В. Васильківський, Ю.О. Ступак, О.М. Семенов // Харчова промисловість. 2008. - № 7. - С. $64-66$.

6. Флауменбаум Б.Л. Основы консервирования пищевых продуктов / Б.Л. Флауменбаум, С.С. Танчев, М.А. Гришин. — Москва : Агропромиздат, 1986. — 494 с.

7. Цуркан О.В. Шляхи інтенсифікації процесу теплової стерилізації консервів на основі його аналізу / О.В. Цуркан, А.Ю. Гурич, Б.М. Пентюк, В.О. Кузь // Збірник наукових праць Вінницького національного аграрного університету № 1(84) 2014p. —C. 170-176. 